Kittova, Z., Steinhauser, D. (2018). The International Economic Position of Western Balkan Countries in Light of their European Integration Ambitions. Journal of Competitiveness, 10(3), 51-68. https://doi. org/10.7441/joc.2018.03.04

\title{
THE INTERNATIONAL ECONOMIC POSITION OF WESTERN BALKAN COUNTRIES IN LIGHT OF THEIR EUROPEAN INTEGRATION AMBITIONS
}

\section{- Zuæana Kittova, Dusan Steinhauser}

\begin{abstract}
From the EU perspective, the Western Balkans region is considered to be an important sphere of interest with the prospect of stepwise EU accession. This is evidenced by establishing a specific accession process for these countries, including an option of granting the status of potential candidate. The progress, particularly concerning the economic preparedness and competitiveness of the Western Balkan countries, is uneven. This paper compares the readiness of particular Western Balkan countries for EU membership on the basis of accession progress assessment, as well as on the basis of international economic position assessment. Taking into account official progress reports published by the European Commission providing a comprehensive assessment of the EU membership criteria, we broaden the perspective of the economic progress assessment by employing the assessment of the international economic positions of the Western Balkan countries based on multifactor indicators. For this purpose, we developed our own composite index of international involvement. We then compared the assessment based on our own index with assessments based on both the Global Competitiveness Index and the Index of Economic Freedom. Based on our findings, the best international economic positions among the Western Balkan countries belong to the Former Yugoslav Republic of Macedonia (FYROM) and Montenegro. Therefore, it may be concluded that accession progress is accompanied by an adequate fit of these economies represented by their international economic position. Contrary to that, Serbia belongs among the worst assessed Western Balkan countries despite its advanced accession progress.
\end{abstract}

Keywords: EU accession, Global Competitiveness Index, Index of Economic Freedom, export performance JEL Classification: B27, C01, C43, F15, F18, F49

Received: December, 2017

1st Revision: March, 2018

Accepted: April, 2018

\section{INTRODUCTION}

The stability of the Balkans has been a key question since the end of the war conflict not only for the countries of this region themselves, but also for the entire European Union or Europe. For this sake, the European Union supports a stabilisation and association process in these 
countries, with the aim of supporting domestic reforms, developing mutual cooperation and preparing for EU membership (for more details, see, e.g., Rivolta, 2011; Fererro-Turrion, 2015). The repeated security instability and domestic political situation in Macedonia proves how topical this matter is (Zubalová, 2015).

Compared to the standard process of joining the European Union, consisting of the three main steps (i.e., 1. granting the status of official candidate for membership, 2. formal membership negotiations, 3. ratification of accession treaty laying down inter alia the date when a country becomes a full EU member), a special process for the Western Balkan countries (including Albania, the Former Yugoslav Republic of Macedonia, Montenegro, Serbia, Kosovo, and Bosnia and Herzegovina) has been established. The European Union's relations with these countries are taking place within a framework known as the stabilisation and association process. This process is based on several instruments such as stabilisation and association agreements (for more details on stabilisation and association agreements, see, e.g., Mardas, 2010; Kašt’áková \& Ružeková, 2014), trade concessions or economic, financial and other types of assistance from the European Union. Moreover, the Western Balkan countries were already offered the prospect of membership. They became potential candidates, meaning that they should be offered official candidate status when they are prepared for it.

\section{THEORETICAL BACKGROUND}

In 1993, the Copenhagen European Council agreed on the requirements for joining the European Union (European Council, 1993). The criteria are grouped into three basic categories, namely the political, economic and institutional criteria. The European Union's capacity to absorb new members, while maintaining the momentum of European integration, is also an important consideration. From the economic point of view, the existence of a functioning market economy is required, and the capacity to cope with competitive pressure and market forces within the European Union is assessed. Both economic criteria encompass groups of sub-criteria. They include, among others, macroeconomic stability, the extent to which government policy and legislation influence competitiveness through trade policy or competition policy, the degree and the pace of trade integration a country achieves with the European Union before enlargement, etc. (for a complete list, see European Commission, 2014). The institutional criteria aim at the ability to take on the obligations of membership. This means that candidate countries are expected to align their legislation with EU law (the so-called acquis) that is presently divided into 35 chapters (such as the free movement of goods, workers, services or capital, corporate law, legislation concerning public procurement, etc.). The requirement for candidates' macroeconomic preparedness is reflected particularly in the chapter on economic and monetary policy, under which member states are subject to the Stability and Growth Pact on fiscal surveillance. Moreover, new member states are expected to comply with the criteria for adopting the common currency (the so-called Maastricht criteria) in due course after accession. Table 1 ranks the Western Balkan countries based on progress made in the accession process.

The country with the greatest progress (ranking 1) is Montenegro, as it is the one of two countries that have already started the accession negotiations focusing on the adoption and implementa- 
tion of the European Union's body of law. Negotiations in three chapters, namely chapter 25 on science and research, chapter 26 on education and culture, and chapter 30 on external relations, have been provisionally closed. Even though it is true that an increased pace of negotiations does not guarantee the quicker accession of a country (i.e., catching-up by countries lagging behind is possible), Montenegro seems to be considerably ahead of Serbia (ranking 2). At the opposite end of the scale, there is Kosovo. This can be explained by the unresolved international status of Kosovo as well as by internal political instability (Reuters, 2015).

Tab. 1 - Comparison of the accession progress. Source: European Commission (2016)

\begin{tabular}{|c|c|c|c|c|c|c|}
\hline Country & Albania & FYROM & $\begin{array}{l}\text { Montene- } \\
\text { gro }\end{array}$ & Serbia & $\begin{array}{l}\text { Bosnia and } \\
\text { Herze- } \\
\text { govina }\end{array}$ & Kosovo \\
\hline $\begin{array}{l}\text { SAA entered } \\
\text { into force }\end{array}$ & April 2009 & April 2004 & May 2010 & $\begin{array}{l}\text { September } \\
2013\end{array}$ & June 2015 & - \\
\hline $\begin{array}{l}\text { Current } \\
\text { status }\end{array}$ & $\begin{array}{l}\text { Candidate } \\
\text { country } \\
\text { since } \\
\text { June } 2014\end{array}$ & $\begin{array}{c}\text { Candidate } \\
\text { country } \\
\text { since } \\
\text { December } \\
2005\end{array}$ & $\begin{array}{l}\text { Candidate } \\
\text { country } \\
\text { since } \\
\text { December } \\
2010\end{array}$ & $\begin{array}{c}\text { Candidate } \\
\text { country } \\
\text { since } \\
\text { March } \\
2012\end{array}$ & $\begin{array}{l}\text { Potential } \\
\text { candidate }\end{array}$ & $\begin{array}{l}\text { Poten- } \\
\text { tial can- } \\
\text { didate }\end{array}$ \\
\hline $\begin{array}{l}\text { Membership } \\
\text { negotiations }\end{array}$ & - & - & June 2012 & $\begin{array}{c}\text { January } \\
2014\end{array}$ & - & - \\
\hline $\begin{array}{l}\text { Negotiations } \\
\text { status:* chap- } \\
\text { ters opened }\end{array}$ & - & - & 28 & 8 & - & - \\
\hline $\begin{array}{l}\text { Negotia- } \\
\text { tions status:* } \\
\text { chapters } \\
\text { provisionally } \\
\text { closed }\end{array}$ & - & - & 3 & 2 & - & - \\
\hline Ranking & 4 & 3 & 1 & 2 & 5 & 6 \\
\hline
\end{tabular}

Legend: SAA - Stabilisation and Association Agreement; * - June 2017.

When dealing with candidate countries, the European Commission assesses the level of compliance with the Copenhagen economic criteria, while in case of potential candidates, it rather refers to a progress achieved towards compliance. The Commission publishes progress reports for each of candidates and potential candidates on yearly basis. As regards the economic criteria, these reports entail i. a. macroeconomic data for the assessed year compared to the previous year, such as the GDP p.c. as a \% of EU28, GDP growth, unemployment rate, economic activity rate for persons aged 20-64, current account balance as a \% of GDP, net FDI as a \% of GDP or budget deficit and public debt as a \% of GDP. In the literature, there are several studies analyzing various aspects of economic situation in the Western Balkan countries. For example, Horuckova \& Lebiedzik (2015) assessed the fulfilment of the Copenhagen economic criteria by 
six Western Balkan countries over the years 2006-2013 and presented results comparable to the European Commission assessments. Klimczak (2016) concentrated on the export performance of six Western Balkan countries in the years 2001 - 2014. He studied factors influencing the export performance of these countries concluding that the external demand played a crucial role, as well as additional supply-type variables such as GDP, GDP p.c. and population. Farkas (2017) analyzed the main institutional areas of a socio-economic system of the Western Balkan countries such as product markets, innovation system, financial system, labour market and industrial relations, social protection and the educational system. She compared them to the post-socialist EU member states and found that there were many similarities between the two regions. However, delayed or unfinished reforms in the Western Balkan countries resulted in a lower openness of economies, weaker competition, poorer development level of innovation systems or extremely low formal employment. These findings are in line with the International Monetary Fund report on achievements of 15 years of economic transition in the Western Balkans (Murgasova et al., 2015). It points to "serious challenges that lie ahead, both in terms of macroeconomic stability and even more so with regard to longer-term development" (p. 5). Valentina \& Esmeralda (2015) measured the key dimensions of creative economy in Western Balkan Countries. They consider the creativity as an "economic driver for generating wealth and employment, sustainable development, technological changes, scientific and business innovation, personal and social development and enhancement of competitiveness of firms, enterprises, individual cities and countries" (p. 2536). The study by Sekuloska (2015) focuses on the role that foreign direct investment (FDI) plays in improving national competitiveness of Western Balkan countries. She emphasizes the quality of FDI (in terms of settling R\&D activities in the host economy) as a crucial factor for improving the production structure of the host economy. Osmani (2017) points to the fact that Western Balkan countries have not been successful enough in attracting FDI. As a consequence, "these countries are well under the real convergence levels of the EU countries" (p. 5).

\section{RESEARCH OBJECTIVE AND METHODOLOGY}

European Commission carries out assessment of the EU membership criteria for both the candidate countries and the potential candidates and publishes progress reports that provide a comprehensive view of examined aspects. However, as regards the economic criteria fulfilment, the comparison among particular countries is rather difficult as it is not directly provided by the reports. In this study, we aim at broadening the perspective of the economic progress assessment by employing the assessment of international economic position of the Western Balkan countries based on multifactorial indicators. This, in our view, is in line with the official criteria of the ability of a country to cope with competitive pressure and market forces within the EU. For this purpose, we compare the assessments provided by internationally recognised organisations (the World Economic Forum and The Heritage Foundation in partnership with Wall Street Journal) that compose indexes reflecting the international economic position of economies, namely the Global Competitiveness Index and the Index of Economic Freedom. Consequently, we compare these results with our assessment based on the composite index of the international involvement. The used indicators provide a simple tool to compare the position of particular Western Balkan countries. Finally, we compare the ranking of the Western Balkan countries based on abovementioned indexes with the ranking of the progress made in the accession process in Table 1. 
The world Economic Forum as a not-for-profit foundation publishes the World Competitiveness Report that provides one of the most comprehensive assessments of national competitiveness. The report ranks national economies on the basis of the Global Competitiveness Index (GCI). The GCI encompasses three sub-indexes, each of them being subdivided further into several pillars (see Table 2). Each pillar combines the set of indicators. In total, there are 114 indicators. The three sub-indexes are given different weights in the calculation of the overall index, depending on each economy's stage of development.

Tab. 2 - Global Competitiveness Index composition. Source: World Economic Forum (2015)

\begin{tabular}{|l|l|}
\hline GCI & Score \\
\hline Sub-index A: Basic requirements & $1-7$ (best) \\
\hline 1st pillar: Institutions & $1-7$ (best) \\
\hline 2nd pillar: Infrastructure & $1-7$ (best) \\
\hline 3rd pillar: Macroeconomic environment & $1-7$ (best) \\
\hline 4th pillar: Health and primary education & $1-7$ (best) \\
\hline Sub-index B: Efficiency enhancers & $1-7$ (best) \\
\hline 5th pillar: Higher education and training & $1-7$ (best) \\
\hline 6th pillar: Goods market efficiency & $1-7$ (best) \\
\hline 7th pillar: Labour market efficiency & $1-7$ (best) \\
\hline 8th pillar: Financial market development & $1-7$ (best) \\
\hline 9th pillar: Technological readiness & $1-7$ (best) \\
\hline 10th pillar: Market size & $1-7$ (best) \\
\hline Sub-index C: Innovation and sophistication factors & $1-7$ (best) \\
\hline 11th pillar: Business sophistication & $1-7$ (best) \\
\hline 12th pillar: Innovation & $1-7$ (best) \\
\hline
\end{tabular}

Secondly, the Index of Economic Freedom provided by The Heritage Foundation in partnership with Wall Street Journal was used. The index measures 10 components of economic freedom that are grouped into 4 pillars, namely:

1. Rule of Law (property rights, freedom from corruption),

2. Limited Government (fiscal freedom, government spending),

3. Regulatory Efficiency (business freedom, labour freedom, monetary freedom),

4. Open Markets (trade freedom, investment freedom and financial freedom).

Each of 10 economic freedoms is graded on a scale from 0 to 100 . Country's overall score is calculated by averaging these 10 economic freedoms, with equal weight being given to each. In our analysis, we use this index because it takes into account the composite measures of trade freedom and investment freedom. According to the 2016 Index of Economic Freedom report, economies rated "free" or "mostly free" enjoy incomes that are over twice the average levels. High income is generated through efficient resource allocation, value creation, and innovation. It asserts that 
economies with higher degrees of economic freedom prosper because of the well-functioning free-market system. „People in economically free societies live longer. They have better health. They are able to be better stewards of the environment, and they push forward the frontiers of human achievement in science and technology through innovation" (Miller \& Kim, 2016).

For the purpose of analyzing the state of economies in the Western Balkan countries, focusing on their involvement in the international labour division, we calculated a composite index of international involvement. Our index includes judgmentally selected data from the publicly accessible database of the World Bank Group. The resulting index is a weighted average of six economic variables. Variables directly expressing the level of the countries' engagement in international trade were assessed with a higher weight. The authors Baláž et al. (2007) proceeded similarly.

In our index, the export performance or the share of export on GDP, regarded as one of the basic competitiveness measures (Baláž et al., 2015), obtained the weight at 20\% share on the overall index. The net inflow of FDI as a share of GDP was treated in the same way obtaining also the weight of $20 \%$ of the overall index. In the current world of an increasing international competition, it is important for a country to produce products with high added value. For this reason, we added in our index the indicator of high-tech export share on total exports, weighting even 30\%. Further, the sub-index of GDP p. c. of productive population at the age between 15 and 64 was used. The indicator of GDP in absolute value is a high value that would distort the overall index, therefore, we expressed GDP in the form of a sub-index. If a country achieved the level of 10,000 USD in the indicator of GDP p.c. 15-64, this country was allocated with a sub-index in the value of 0.5 . For each increment of 10,000 USD, a country obtained further 0.5 . This sub-index was assigned the weight of $10 \%$. The unemployment (measured by the methodology of the International Labour Organisation) and inflation rates have a $10 \%$ weight in the overall index, but these macroeconomic indicators worsen the value of the index. We added them to the calculation as they complete the picture of the overall economic situation in the analysed countries. The index constructed in this way is significantly influenced by country's performance (measured by the sub-index of GDP p. c. on productive population), and by the extent of involvement of a country in the foreign trade exchange (measured by the export performance and by the share of the hightech export). The higher index level means the higher country assessment.

Tab. 3 - Components of the composite index of international involvement. Source: own processing

\begin{tabular}{|l|c|}
\hline Indicator & Weight (coeff.) \\
\hline Foreign direct investment, net inflows (\% of GDP, coeff.) & 0.2 \\
\hline GDP, PPP index per capita (15-64) & 0.1 \\
\hline High-technology exports (\% of manufactured exports, coeff.) & 0.3 \\
\hline Inflation, GDP deflator (annual \%, coeff.) & -0.1 \\
\hline Exports of goods and services (\% of GDP, coeff.) & 0.2 \\
\hline Unemployment, total (\% of total labour force, coeff.) (mod. ILO est.) & -0.1 \\
\hline
\end{tabular}




\section{RESULTS}

This section entails results of the international economic position assessment of the Western Balkan countries measured by three indexes, namely the Global Competitiveness Index, the Index of Economic Freedom and the composite index of international involvement.

\subsection{Global Competitiveness Index}

The developments in the global competitiveness of the Western Balkan Countries in the years $2005-2015$ can be seen in Table 4.

Tab. 4 - Western Balkan countries' values of the GCI. Source: World Economic Forum (20052015)

\begin{tabular}{|l|l|l|l|l|l|l|l|l|l|l|l|}
\hline Country & 2005 & 2006 & 2007 & 2008 & 2009 & 2010 & 2011 & 2012 & 2013 & 2014 & 2015 \\
\hline Albania & 3.07 & 3.46 & 3.48 & 3.55 & 3.72 & 3.94 & 4.06 & 3.91 & 3.85 & 3.84 & 3.92 \\
\hline $\begin{array}{l}\text { Bosnia and } \\
\text { Herze- } \\
\text { govina }\end{array}$ & 3.17 & 3.67 & 3.55 & 3.56 & 3.53 & 3.7 & 3.83 & 3.93 & 4.02 & $\mathrm{n} / \mathrm{a}$ & 3,70 \\
\hline Kosovo & $\mathrm{n} / \mathrm{a}$ & $\mathrm{n} / \mathrm{a}$ & $\mathrm{n} / \mathrm{a}$ & $\mathrm{n} / \mathrm{a}$ & $\mathrm{n} / \mathrm{a}$ & $\mathrm{n} / \mathrm{a}$ & $\mathrm{n} / \mathrm{a}$ & $\mathrm{n} / \mathrm{a}$ & $\mathrm{n} / \mathrm{a}$ & $\mathrm{n} / \mathrm{a}$ & $\mathrm{n} / \mathrm{a}$ \\
\hline FYROM & 3.26 & 3.86 & 3.73 & 3.87 & 3.95 & 4.02 & 4.05 & 4.04 & 4.14 & 4.26 & 4.28 \\
\hline $\begin{array}{l}\text { Montene- } \\
\text { gro }\end{array}$ & 3.38 & 3.69 & 3.91 & 4.11 & 4.14 & 4.36 & 4.27 & 4.14 & 4.2 & 4.23 & 4.20 \\
\hline Serbia & 3.38 & 3.69 & 3.78 & 3.9 & 3.77 & 3.84 & 3.88 & 3.87 & 3.77 & 3.89 & 3.88 \\
\hline
\end{tabular}

According to the 2015-2016 Global Competitiveness Report (World Economic Forum, 2015), the ranking of Albania improved by four positions to 93. Among the factors that are the most problematic for Albania's competitiveness, there are: companies' narrow presence in the value chain, low quality of scientific research institutions, insufficient university-industry collaboration in R\&D, low efficiency of financial markets due to the mainly insufficient financing through a local equity market as well as low venture capital and financial services availability, under-developed clusters (i.e. geographic concentrations of firms, suppliers, producers of related products and services in a particular field).

Bosnia and Herzegovina reached the 111th position in the World Economic Forum ranking. The most significant weaknesses of this country are: low quality of transport infrastructure, low buyer sophistication meaning that buyer's purchasing decisions are based on the lowest price, inefficient use of talents that influences the labour market efficiency in a negative way, low involvement of the government in procurement of advanced technology products, companies' low capacity to innovate, companies' failure to use marketing to differentiate their products and services.

FYROM with the 60th position in the ranking has the most competitive economy within the Western Balkan countries. However, improvement has to be made regarding the country's capacity to attract and retain talent, primary education enrolment rate as well as willingness to delegate authority to subordinates. Moreover, competitive advantage of the country's companies in international markets is based primarily on low-cost labour or natural resources. 
The second best ranking within the region, namely the 70th position, belongs to Montenegro. The competitiveness of Montenegro is negatively influenced mainly by a low level of gross national savings, small domestic market, low value of exports of goods and services, the state of cluster development, a low number of local suppliers, insufficient cooperation in labour-employer relations as well as insufficient reliance on professional management.

Serbia's position (ranking 94) in the World Economic Forum ranking remains stable in the last two years and is the worst one out of the Western Balkans countries. It is influenced by:

- inefficient use of talent mainly due to a low capacity to retain and attract talent,

- low business sophistication resulting from the nature of competitive advantage based primarily on low-cost labour or natural resources, companies' failure to use marketing to differentiate their products and services, insufficient willingness to delegate authority to subordinates and a low level of production process' sophistication,

- unsatisfactory public sector performance (mainly high burden of government regulation and wastefulness of government spending),

- low companies' investment in training and employee development, a low level of protection of minority shareholders' interests, insufficient cooperation in labour-employer relations, low capacity for innovation as well as low company spending on $\mathrm{R} \& \mathrm{D}$, etc.

The values of export performance and of the GCI for all Western Balkan countries in the period since 2005 to 2014 are shown in Figure 1 below. We were interested in the relation between the values of export performance (EP) and the GCI. Due to data availability, 49 observations of indicated pairs were noted. For the purpose of clarity, we noted symbolically the three measures of country's involvement in the international labour division (Kašt’áková \& Ružeková, 2012):

openess rate $=\left(\sum\right.$ export + import $) /$ gross domestic product

export performance $=$ Eexport $/$ gross domestic product

import performance $=$ import / gross domestic product

We verified the observed relationship by a correlation analysis despite the fact that we were investigating the relation between variables of six countries. We assumed homogeneity of the statistical population since the GCI approved in each country using the same methodology. The correlation coefficient was calculated by the software Gretl:

$\operatorname{corr}(G C I, E V)=0,52570904$

The null hypothesis of no correlation:

$t(47)=4,23678$, with two-tailed p-value 0,0001.

The correlation coefficient 0.53 corresponds to a moderately strong dependence between variables, indicating that development in competitiveness of the Western Balkan countries measured by the GCI is directly proportionally accompanied by export performance of these countries. 


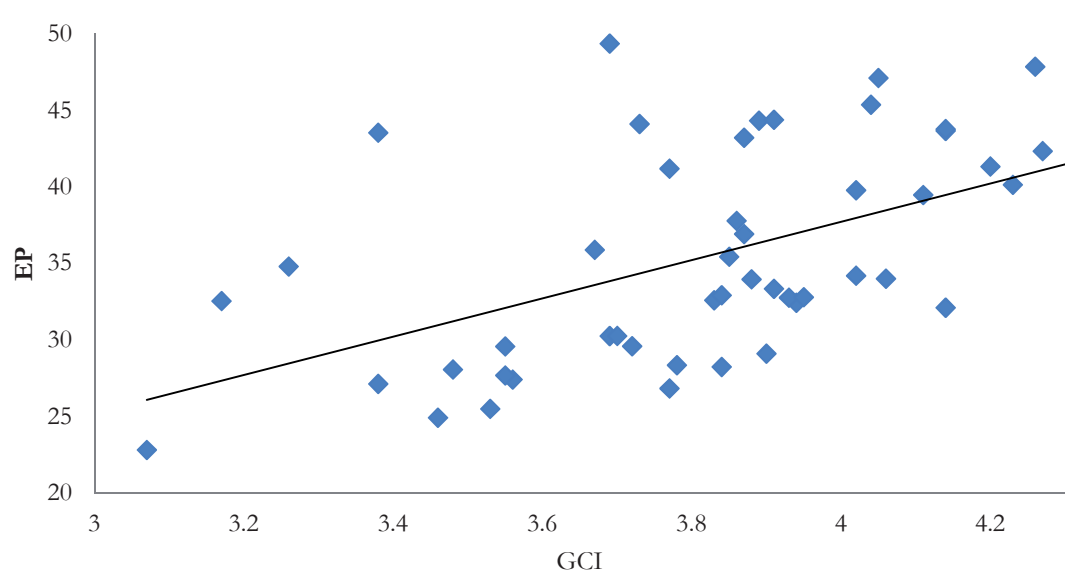

Fig. 1 - Actual and fitted EP versus the GCI. Source: output from the program Gretl, based on World Economic Forum (2005-2015), WBG (2015-2016)

Legend: EP = export performance, GCI = Global Competitiveness Index.

Table 5 presents comparison of the performance measured by the GCI value of the Western Balkan countries with the average value for the $28 \mathrm{EU}$ member states as well as with the performance of the 6 EU member states with the lowest GCI values during 2013 - 2015. It is apparent that the difference between the GCI values of the Western Balkan countries and the 6 EU member states is not significant. However, compared to the EU28 average, the difference is notable. Moreover, in 2015 the average GCI value for the Western Balkan countries and for the EU28 moved divergently when compared in comparison with to the previous year.

Tab. 5 - Comparison of the GCI values. Source: World Economic Forum (2005-2015)

\begin{tabular}{|l|l|l|l|l|l|l|l|}
\hline Country & 2013 & 2014 & 2015 & Country & 2013 & 2014 & 2015 \\
\hline Albania & 3.85 & 3.84 & 3.92 & Croatia & 4.13 & 4.13 & 4.07 \\
\hline $\begin{array}{l}\text { Bosnia and Herze- } \\
\text { govina }\end{array}$ & 4.02 & $\mathrm{n} / \mathrm{a}$ & 3.70 & Greece & 3.93 & 4.04 & 4.02 \\
\hline Kosovo & $\mathrm{n} / \mathrm{a}$ & $\mathrm{n} / \mathrm{a}$ & $\mathrm{n} / \mathrm{a}$ & Hungary & 4.25 & 4.28 & 4.25 \\
\hline FYROM & 4.14 & 4.26 & 4.28 & Romania & 4.13 & 4.30 & 4.32 \\
\hline Montenegro & 4.20 & 4.23 & 4.20 & Slovakia & 4.10 & 4.15 & 4.22 \\
\hline Serbia & 3.77 & 3.89 & 3.88 & Slovenia & 4.25 & 4.22 & 4.28 \\
\hline \multirow{2}{*}{ WB average } & 4.00 & 4.06 & 4.00 & EU6 average & 4.13 & 4.19 & 4.19 \\
\cline { 5 - 9 } & & & & & & & \\
\end{tabular}

\subsection{Index of Economic Freedom}

Table 6 shows the overall result of the Index of Economic Freedom from 2013 to 2016. The Index of Economic Freedom is published at the beginning of a calendar year, therefore, i.e. the 2016 score reflects the situation in 2015. 
Tab. 6 - Comparison of the Index of Economic Freedom values. Source: The Heritage (2013 $-2016)$

\begin{tabular}{|l|l|l|l|l|l|l|l|l|l|}
\hline Country & $\begin{array}{l}2013 \\
\text { Score }\end{array}$ & $\begin{array}{l}2014 \\
\text { Score }\end{array}$ & $\begin{array}{l}2015 \\
\text { Score }\end{array}$ & $\begin{array}{l}2016 \\
\text { Score }\end{array}$ & Country & $\begin{array}{l}2013 \\
\text { Score }\end{array}$ & $\begin{array}{l}2014 \\
\text { Score }\end{array}$ & $\begin{array}{l}2015 \\
\text { Score }\end{array}$ & $\begin{array}{l}2016 \\
\text { Score }\end{array}$ \\
\hline Albania & 65.2 & 66.9 & 65.7 & 65.9 & Croatia & 61.3 & 60.4 & 61.5 & 59.1 \\
\hline $\begin{array}{l}\text { Bosnia and } \\
\text { Herze- } \\
\text { govina }\end{array}$ & 57.3 & 58.4 & 59.0 & 58.6 & France & 64.1 & 63.5 & 62.5 & 62.3 \\
\hline FYROM & 68.2 & 68.6 & 67.1 & 67.5 & Greece & 55.4 & 55.7 & 54.0 & 53.2 \\
\hline Montenegro & 62.6 & 63.6 & 64.7 & 64.9 & Italy & 60.6 & 60.9 & 61.7 & 61.2 \\
\hline Serbia & 58.6 & 59.4 & 60.0 & 62.1 & Portugal & 63.1 & 63.5 & 65.3 & 65.1 \\
\hline Kosovo & $\mathrm{n} / \mathrm{a}$ & $\mathrm{n} / \mathrm{a}$ & $\mathrm{n} / \mathrm{a}$ & 61.4 & Slovenia & 61.7 & 62.7 & 60.3 & 60.6 \\
\hline WB average & 62.4 & 63.4 & 63.3 & 63.4 & EU6 average & 61.0 & 61.1 & 60.9 & 60.3 \\
\cline { 5 - 11 } & & & & EU28 average & 68.7 & 68.8 & 69.0 & 69.0 \\
\hline
\end{tabular}

When commenting on results of the Index of Economic Freedom, it is interesting to note that the Western Balkan countries are reaching higher average values than average values for the 6 EU member states with the lowest 2016 score. In comparison to the EU28 average though, the Western Balkan countries are reaching substantively lower average values. The best assessment belongs to the economy of FYROM in the long run, followed by Albania, Montenegro and Serbia. The worst result goes to Bosnia and Herzegovina. According to the 2016 Index of Economic Freedom report, five Western Balkan countries (Albania, FYROM, Kosovo, Montenegro and Serbia) belong to the group of moderately free economies. Bosnia and Herzegovina is the only Western Balkan country that is mostly unfree. Fourteen EU member states qualified as mostly free economies, two EU member states (Greece and Croatia) as mostly unfree. The rest of the EU member states belong to the group of moderately free economies. Table 7 summarises the results of the index and its 10 economic freedoms in 2016. It can be seen that FYROM, Albania, Montenegro and Serbia reached the best assessment in the Fiscal Freedom (F) and Trade Freedom (T), Bosnia a Hercegovina in the Trade Freedom (T) and Monetary Freedom (M), Kosovo in the Fiscal Freedom (F) and Monetary Freedom (M).

Tab. 7 - Index of Economic Freedom. Source: The Heritage (2013 - 2016)

\begin{tabular}{|l|l|l|l|l|l|l|l|l|l|l|l|}
\hline Country & $\begin{array}{l}2016 \\
\text { Score }\end{array}$ & P & C & F & G & B & L & M & T & I & Fin \\
\hline Albania & 65.9 & 35.0 & 33.0 & 87.8 & 75.0 & 67.6 & 51.5 & 81.7 & 87.6 & 70.0 & 70.0 \\
\hline $\begin{array}{l}\text { Bosnia and } \\
\text { Herze- } \\
\text { govina }\end{array}$ & 58.6 & 20.0 & 39.0 & 83.9 & 33.1 & 54.6 & 59.4 & 84.3 & 87.0 & 65.0 & 60.0 \\
\hline Macedonia & 67.5 & 35.0 & 45.0 & 92.1 & 69.6 & 76.4 & 66.7 & 83.5 & 86.4 & 60.0 & 60.0 \\
\hline $\begin{array}{l}\text { Montene- } \\
\text { gro }\end{array}$ & 64.9 & 40.0 & 42.0 & 91.6 & 39.8 & 76.6 & 72.0 & 82.6 & 84.8 & 70.0 & 50.0 \\
\hline
\end{tabular}




\begin{tabular}{|l|l|l|l|l|l|l|l|l|l|l|l|}
\hline Serbia & 62.1 & 50.0 & 41.0 & 84.3 & 44.1 & 60.2 & 66.2 & 77.5 & 77.8 & 70.0 & 50.0 \\
\hline Kosovo & 61.4 & 30.0 & 33.0 & 93.6 & 76.8 & 69.3 & 66.3 & 78.9 & 70.8 & 65.0 & 30.0 \\
\hline WB average & 63.4 & 35.0 & 38.8 & 88.9 & 56.4 & 67.5 & 63.7 & 81.4 & 82.4 & 66.7 & 53.3 \\
\hline Croatia & 59.1 & 35.0 & 48.0 & 70.8 & 33.7 & 60.3 & 42.4 & 78.7 & 87.4 & 75.0 & 60.0 \\
\hline France & 62.3 & 80.0 & 69.0 & 47.7 & 2.5 & 78.4 & 43.5 & 79.1 & 83.0 & 70.0 & 70.0 \\
\hline Greece & 53.2 & 40.0 & 43.0 & 64.4 & 0.0 & 73.8 & 50.2 & 77.7 & 83.0 & 60.0 & 40.0 \\
\hline Italy & 61.2 & 50.0 & 43.0 & 55.8 & 22.1 & 70.3 & 53.0 & 84.5 & 88.0 & 85.0 & 60.0 \\
\hline Portugal & 65.1 & 70.0 & 63.0 & 60.5 & 24.8 & 85.3 & 43.5 & 85.7 & 88.0 & 70.0 & 60.0 \\
\hline Slovenia & 60.6 & 60.0 & 58.0 & 58.6 & 0.0 & 82.0 & 55.4 & 84.3 & 88.0 & 70.0 & 50.0 \\
\hline $\begin{array}{l}\text { EU28 aver- } \\
\text { age }\end{array}$ & 69.0 & 69.5 & 64.2 & 66.8 & 33.9 & 77.0 & 58.8 & 83.1 & 87.6 & 80.9 & 67.9 \\
\hline
\end{tabular}

Legend: Property Rights (P), Freedom from Corruption (C), Fiscal Freedom (F), Government Spending (G), Business Freedom (B), Labour Freedom (L), Monetary Freedom (M), Trade Free$\operatorname{dom}(\mathrm{T})$, Investment Freedom (I), Financial Freedom (Fin).

Using the software Statgraphics PLUS 5.1, a k-means cluster analysis was performed where the Western Balkan countries were assigned to pre-defined clusters according to those EU member states with the lowest overall 2016 score in the Index of Economic Freedom. Only sub-indexes were included into our analysis, without the overall score value, for all Western Balkan Countries and the EU, 34 countries in total. Table 8 contains the result of this analysis. Assignment to a cluster means that the respective Western Balkan country is the most similar to the respective EU member state. Albania, FYROM as well as Bosnia and Herzegovina are located in the same cluster being defined on the basis of Croatia, Montenegro on the basis of Slovenia, Serbia and Kosovo are in the Greek cluster.

Tab. 8 - Cluster analysis. Source: own processing from the program Statgraphics PLUS 5.1

\begin{tabular}{|l|l|}
\hline Western Balkans countries & Cluster \\
\hline Albania & Croatia \\
\hline Bosnia and Herzegovina & Croatia \\
\hline Macedonia & Croatia \\
\hline Montenegro & Slovenia \\
\hline Serbia & Greece \\
\hline Kosovo & Greece \\
\hline
\end{tabular}

\subsection{Composite index of international involvement}

We calculated the index of international involvement for the period from 2005 to 2014 (see Table 9 and Table 10). Table 9 presents the values of particular components of the composite index of international involvement for the years 2014 and 2013. Due to the missing data on high-tech exports, it was only possible to calculate the composite index for the year 2013 and for 3 countries. To calculate the composite values for more countries, we were considering a possibility to 
exclude this indicator from the composite index, however, we concluded that this would lower the explanatory power of the index. Moreover, the composite index was originally created with the aim to measure the national competitiveness of the EU member states (Fifek et al., 2015). In this study, we are extending its scope to the potential EU members in the Western Balkan. Hence, we preferred to maintain the structure of the composite index so that we would be able to compare the results gained. In order to compare the Western Balkan countries with the EU member states, we calculated the average values of the international involvement index for all EU member states, as well as for those 6 EU member states achieving the lowest index values in 2013. One more limitation of our assessment concerns Kosovo, for which we were able to get the data on 3 indicators only.

The overall result of the index is affected mostly by economy performance and export performance. The best GDP p.c. $(15$ - 64) sub-index result was reached by Montenegro for both years (value 0.15). The other Western Balkan countries evenly achieved the value of 0.1 in this subindex. They differ in the level of involvement in the foreign trade exchange, as represented by the export performance. The best value in this sub-index (at the level of 0.096) was reached by FYROM. Better results of result for all countries could be reached by inflow of foreign direct investments.

Tab. 9 - Composite index of international involvement (2013, 2014). Source: Own calculation based on WBG (2015 - 2016)

\begin{tabular}{|c|c|c|c|c|c|c|c|c|c|}
\hline & $\underset{\widetilde{J}}{\tilde{\nu}}$ & 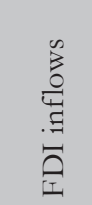 & 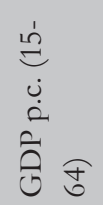 & 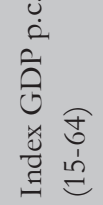 & 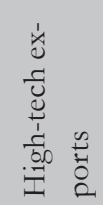 & 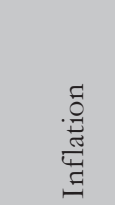 & 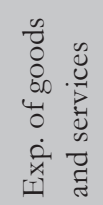 & 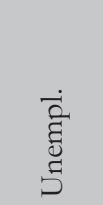 & 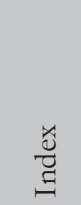 \\
\hline Weight & & 0.2 & & 0.1 & 0.3 & -0.1 & 0.2 & -0.1 & \\
\hline \multirow{2}{*}{ Albania } & 2013 & 0.020 & 14266 & 0.100 & 0.002 & -0.0002 & 0.071 & -0.016 & 0.176 \\
\hline & 2014 & 0.017 & 14933 & 0.100 & $\mathrm{n} / \mathrm{a}$ & -0.0010 & 0.056 & -0.016 & $\mathrm{n} / \mathrm{a}$ \\
\hline \multirow{2}{*}{$\begin{array}{l}\text { Bosnia and } \\
\text { Herze- } \\
\text { govina }\end{array}$} & 2013 & 0.004 & 13340 & 0.100 & 0.007 & 0.0003 & 0.068 & -0.027 & 0.152 \\
\hline & 2014 & 0.005 & 13857 & 0.100 & $\mathrm{n} / \mathrm{a}$ & -0.0018 & 0.069 & -0.028 & $\mathrm{n} / \mathrm{a}$ \\
\hline \multirow{2}{*}{ Kosovo } & 2013 & 0.010 & $\mathrm{n} / \mathrm{a}$ & $\mathrm{n} / \mathrm{a}$ & $\mathrm{n} / \mathrm{a}$ & -0.0018 & 0.035 & $\mathrm{n} / \mathrm{a}$ & $\mathrm{n} / \mathrm{a}$ \\
\hline & 2014 & 0.005 & $\mathrm{n} / \mathrm{a}$ & $\mathrm{n} / \mathrm{a}$ & $\mathrm{n} / \mathrm{a}$ & -0.0032 & 0.039 & $\mathrm{n} / \mathrm{a}$ & $\mathrm{n} / \mathrm{a}$ \\
\hline \multirow{2}{*}{ FYROM } & 2013 & 0.007 & 17591 & 0.100 & 0.011 & -0.0043 & 0.088 & -0.029 & 0.173 \\
\hline & 2014 & 0.001 & 18555 & 0.100 & $\mathrm{n} / \mathrm{a}$ & -0.0014 & 0.096 & -0.028 & $\mathrm{n} / \mathrm{a}$ \\
\hline \multirow{2}{*}{$\begin{array}{l}\text { Montene- } \\
\text { gro }\end{array}$} & 2013 & 0.020 & 21083 & 0.150 & $\mathrm{n} / \mathrm{a}$ & -0.0021 & 0.083 & -0.020 & $\mathrm{n} / \mathrm{a}$ \\
\hline & 2014 & 0.022 & 21151 & 0.150 & $\mathrm{n} / \mathrm{a}$ & -0.0010 & 0.080 & -0.019 & $\mathrm{n} / \mathrm{a}$ \\
\hline \multirow{2}{*}{ Serbia } & 2013 & 0.009 & 19387 & 0.100 & $\mathrm{n} / \mathrm{a}$ & -0.0054 & 0.082 & -0.022 & $\mathrm{n} / \mathrm{a}$ \\
\hline & 2014 & 0.009 & 18925 & 0.100 & $\mathrm{n} / \mathrm{a}$ & -0.0019 & 0.089 & -0.022 & $\mathrm{n} / \mathrm{a}$ \\
\hline
\end{tabular}

Legend: Foreign direct investment, net inflows as share on GDP (FDI), GDP PPP p. c. on population of age between 15- 64 (GDP p. c. 15-64), High-technology exports as share on manufactured exports (High-tech 
exports), Inflation as centesimal of GDP deflator (Inflation), Exports of goods and services as share on GDP (Exp.), Total unemployment, modelled ILO estimation as share on total labour force (Unempl.).

Table 10 illustrates comparison of the Western Balkan countries with the EU member states with the lowest score reached in the index of international involvement in 2013. Due to the lack of partial data, it was possible to assess only 3 Western Balkan countries for the whole in-scope period (Albania, FYROM, Bosnia and Herzegovina) and Serbia for 2005 - 2007. As a result of this, it was not possible to apply the index of international involvement for further quantitative analysis. The Western Balkan countries reached lower average values of international involvement index than those EU countries with the lowest result in this index, and far lower values than the average for the EU 28. One of the reasons is that the EU countries reach higher economic performance measured in GDP than the Western Balkan countries.

Tab. 10 - Comparison of the composite index of international involvement values. Source: Own processing.

\begin{tabular}{|l|l|l|l|l|l|l|l|l|l|}
\hline Country & 2005 & 2006 & 2007 & 2008 & 2009 & 2010 & 2011 & 2012 & 2013 \\
\hline Albania & 0.100 & 0.161 & 0.155 & 0.172 & 0.168 & 0.167 & 0.170 & 0.168 & 0.176 \\
\hline $\begin{array}{l}\text { Bosnia and } \\
\text { Herzegovina }\end{array}$ & 0.103 & 0.153 & 0.150 & 0.147 & 0.138 & 0.145 & 0.149 & 0.148 & 0.152 \\
\hline Kosovo & $\mathrm{n} / \mathrm{a}$ & $\mathrm{n} / \mathrm{a}$ & $\mathrm{n} / \mathrm{a}$ & $\mathrm{n} / \mathrm{a}$ & $\mathrm{n} / \mathrm{a}$ & $\mathrm{n} / \mathrm{a}$ & $\mathrm{n} / \mathrm{a}$ & $\mathrm{n} / \mathrm{a}$ & $\mathrm{n} / \mathrm{a}$ \\
\hline FYROM & 0.135 & 0.152 & 0.169 & $\mathrm{n} / \mathrm{a}$ & 0.147 & 0.162 & 0.181 & 0.177 & 0.173 \\
\hline Montenegro & $\mathrm{n} / \mathrm{a}$ & $\mathrm{n} / \mathrm{a}$ & $\mathrm{n} / \mathrm{a}$ & $\mathrm{n} / \mathrm{a}$ & $\mathrm{n} / \mathrm{a}$ & $\mathrm{n} / \mathrm{a}$ & $\mathrm{n} / \mathrm{a}$ & $\mathrm{n} / \mathrm{a}$ & $\mathrm{n} / \mathrm{a}$ \\
\hline Serbia & 0.144 & 0.171 & 0.163 & $\mathrm{n} / \mathrm{a}$ & $\mathrm{n} / \mathrm{a}$ & $\mathrm{n} / \mathrm{a}$ & $\mathrm{n} / \mathrm{a}$ & $\mathrm{n} / \mathrm{a}$ & $\mathrm{n} / \mathrm{a}$ \\
\hline WB average & 0.121 & 0.159 & 0.159 & 0.159 & 0.151 & 0.158 & 0.166 & 0.165 & 0.167 \\
\hline Spain & 0.313 & 0.313 & 0.316 & 0.312 & 0.298 & 0.306 & 0.310 & 0.312 & 0.316 \\
\hline Poland & 0.168 & 0.235 & 0.235 & 0.235 & 0.238 & 0.246 & 0.297 & 0.300 & 0.304 \\
\hline Bulgaria & 0.211 & 0.244 & 0.267 & 0.299 & 0.264 & 0.277 & 0.286 & 0.292 & 0.303 \\
\hline Croatia & 0.255 & 0.257 & 0.255 & 0.304 & 0.247 & 0.243 & 0.292 & 0.300 & 0.294 \\
\hline Greece & 0.263 & 0.317 & 0.307 & 0.314 & 0.309 & 0.310 & 0.311 & 0.262 & 0.261 \\
\hline Romania & 0.172 & 0.180 & 0.161 & 0.217 & 0.227 & 0.239 & 0.246 & 0.235 & 0.240 \\
\hline EU6 average & 0.230 & 0.257 & 0.257 & 0.280 & 0.264 & 0.270 & 0.290 & 0.284 & 0.286 \\
\hline EU28 average & 0.382 & 0.405 & 0.407 & 0.423 & 0.399 & 0.444 & 0.441 & 0.435 & 0.404 \\
\hline
\end{tabular}

We will now elaborate on the relative positions of the countries which already accessed the Union and what index results they had. Figures 2 and 3 show the development of two basic measures used when comparing economic performance or the competitiveness of economies, i.e., the export performance and the GDP p.c. These figures illustrate the significance of the gap between the Western Balkan countries and the EU average and show a comparison also with the situation of the newest EU member states (Croatia since 2013, Bulgaria and Romania since 2007) prior to their accession as well as after accession. As far as export performance is concerned, the average value for Bulgaria and Romania increased from 35\% in 2008 to more than $50 \%$ in 2015. At the same time, however, the export performance of the EU 25 increased by 15 percentage points, thus leaving the gap almost unchanged. The GDP p.c. values for Bulgaria and Romania 
have remained stable since accession. The EU25 registered a slight decrease of GDP p.c. since 2008. The export performance of Croatia has increased since accession, however, a positive trend needs to be confirmed over a longer time period. Contrary to that, the GDP p.c. has decreased in Croatia since 2014. We may conclude that from the short-term perspective (Croatia) or mid-term perspective (Bulgaria and Romania), EU membership did not result in accelerating the catching up process. Similarly, we expect the same in the case of the accession of Western Balkan countries.

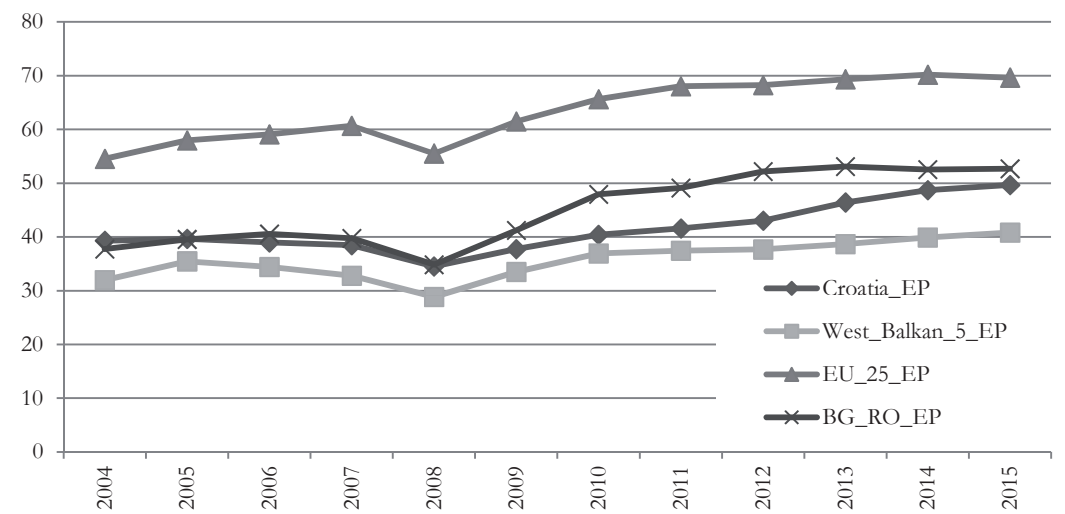

Fig. 2 - Export performance. Source: own calculation based on WBG (2018)

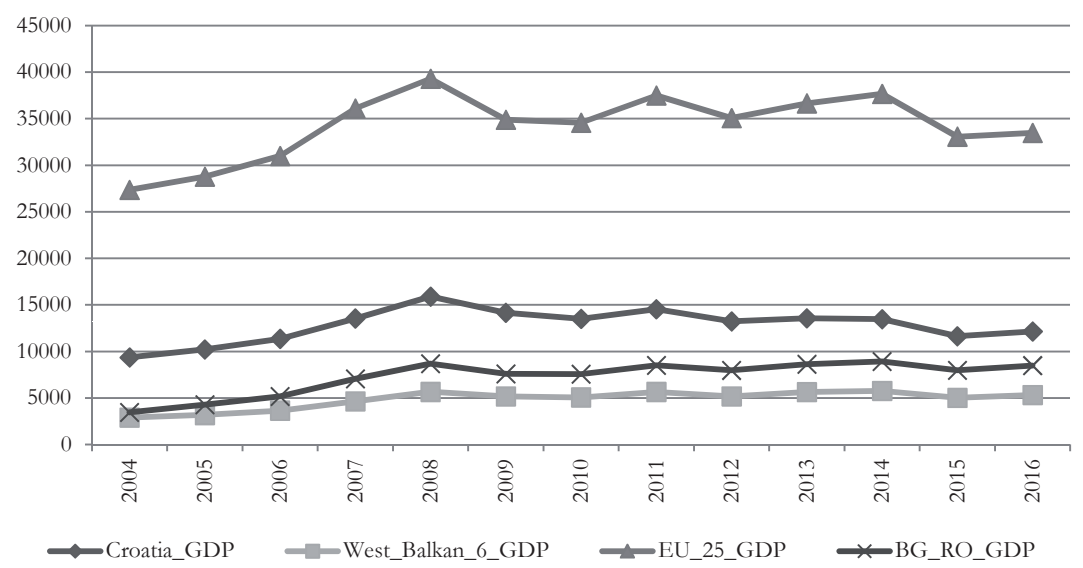

Fig. 3 - Gross Domestic Product per capita. Source: own calculation based on WBG (2018)

\section{CONCLUSION}

The most recent assessment of the Western Balkan countries available and published by the European Commission points to a low level of economic competitiveness: "Critical parts of the region's economies are uncompetitive. None of the Western Balkans can currently be considered a functioning market economy nor to have the capacity to cope with the competitive 
pressure and market forces in the union.” (European Commission, 2018, p. 2) Although the EU reports on progress made by the Western Balkan countries towards accession include detailed information on the economic situation (including macroeconomic data) of each country, they are not intended to serve as a comparative tool. Obviously, for political and diplomatic reasons, the European Union is not in favour of creating a ranking of the "best" candidates. Therefore, we based our approach on multifactor indexes that serve as comprehensive measures of the international economic position of each country concerned. We chose two indexes calculated by recognized institutions that involve a wide range of assessed criteria, and we supplemented the analyses with our own index. On the basis of the GCI, the Index of Economic Freedom and the composite index of international involvement values of the Western Balkan countries, it is possible to compare the performance of the Western Balkan countries and create a ranking where value 1 represents the country with the best index results within the region.

Tab. 11 - Ranking of the Western Balkan countries. Source: own calculation

\begin{tabular}{|l|l|l|l|l|l|l|}
\hline Country & $\begin{array}{l}\text { GCI- } \\
\text { ranking } \\
2013\end{array}$ & $\begin{array}{l}\text { GCI- } \\
\text { ranking } \\
2015\end{array}$ & $\begin{array}{l}\text { Index of } \\
\text { economic } \\
\text { freedom } \\
\text { ranking }\end{array}$ & $\begin{array}{l}\text { Index of } \\
\text { economic } \\
\text { freedom } \\
\text { ranking }\end{array}$ & $\begin{array}{l}\text { Composite } \\
\text { index rank- } \\
\text { ing 2013 }\end{array}$ & $\begin{array}{l}\text { Ranking } \\
\text { based on } \\
\text { accession } \\
\text { progress }\end{array}$ \\
\hline Albania & 4 & 3 & 2 & 2 & 1 & 4 \\
\hline $\begin{array}{l}\text { Bosnia and } \\
\text { Herzegovina }\end{array}$ & 3 & 5 & 5 & 6 & 3 & 5 \\
\hline Kosovo & $\mathrm{n} / \mathrm{a}$ & $\mathrm{n} / \mathrm{a}$ & $\mathrm{n} / \mathrm{a}$ & 5 & $\mathrm{n} / \mathrm{a}$ & 6 \\
\hline FYROM & 2 & 1 & 1 & 1 & 2 & 3 \\
\hline Montenegro & 1 & 2 & 3 & 3 & $\mathrm{n} / \mathrm{a}$ & 1 \\
\hline Serbia & 5 & 4 & 4 & 4 & $\mathrm{n} / \mathrm{a}$ & 2 \\
\hline
\end{tabular}

Legend: The 2014 Index of Economic Freedom ranking is calculated on the basis of indicators in 2013. Similarly, the 2016 Index is calculated on the basis of indicators in 2015 .

Table 11 presents an evaluation of the overall international economic position of individual Western Balkan countries on the basis of their scores according to three analysed indexes. This evaluation is made for 2013 due to the fact that the data needed to calculate the composite index of international involvement was the most current. When more recent data was available, we included comparative results for 2015. This enables observing the progress of particular countries. Incomplete data represents the most significant limitation of the assessment based on the composite index of international involvement. Nevertheless, it is possible to compare available indicators creating the components of the composite index. A further limitation of our research is that it uses quantitative data only. Thus, explanatory power is limited with regard to expressing quality (e.g., export performance does not express the quality of the country's exports). Moreover, it may be argued that the chosen indicators do not sufficiently cover all relevant aspects. We decided to base our index on indicators that can be readily calculated from the data available. Moreover, we found support for the selection of indicators in the relevant literature. Another limitation of our research is a short time series of observations. For this reason, we recommend a 
continuous monitoring of the accession countries, using both soft and hard indicators to achieve objectivity. Our article may provide guidance on methods for further scientific studies.

Finally, we compared the results gained from the accession progress, as analysed in Table 1 . The best overall economic position among the Western Balkan countries belongs to FYROM and Montenegro according to our findings. Conversely, countries assessed as the worst are Serbia, Kosovo and Bosnia and Herzegovina. While in the cases of Montenegro and FYROM, the accession progress is accompanied by the adequate readiness of their economies expressed by their international economic position, Serbia should increase the pace of its economic reforms during the accession period, aiming at improving its economic readiness for joining the European Union.

Acknowledgement

This paper is a result of scientific research conducted at the Faculty of Commerce, University of Economics in Bratislava, within the framework of the VEGA project No. 1/0897/17 (responsible researcher: prof. Ing. Peter Baláž, PhD.).

\section{References}

1. Baláž, P., Hamara, A., \& Sopková, G. (2015). Konkurencieschopnost’ a jej výżnam v národnej ekonomike. Bratislava, Slovakia: Sprint 2.

2. Baláž, V., Kluvánková-Oravská, T., \& Zajac, Š. (2007). Inštitúcie a ekonomická transformácia. Bratislava, Slovakia: VEDA Vydavatel'stvo Slovenskej akadémie vied.

3. European Commission. (2014). Progress towards meeting the economic criteria for EU accession: The EU Commission's 2014 assessments. European Economy. Brussels: European Commission. Retrieved November 14, 2017, from http://ec.europa.eu/economy_finance/publications/ occasional_paper/2014/pdf/ocp205_en.pdf. doi:10.2765/85464.

4. European Commission. (2016). European neighbourhood policy and enlargement negotiations. Brussels: European Commission. Retrieved November 3, 2017, from http://ec.europa.eu/enlargement/ countries/check-current-status/index_en.htm.

5. European Commission. (2018). A credible enlargement perspective for and enhanced EU engagement with the Western Balkans. Strasbourg: European Commission. Retrieved March, 2018, from https:// ec.europa.eu/commission/sites/beta-political/files/communication-credible-enlargementperspective-western-balkans_en.pdf

6. European Council. (1993). European Council in Copenhagen 21-22 June 1993. Conclusions of the presidency. Copenhagen: European Council. Retrieved November, 14, 2017, from http://www. consilium.europa.eu/ueDocs/cms_Data/docs/pressData/en/ec/72921.pdf .

7. Farkas, B. (2017). Market economies of the Western Balkans compared to the Central and Eastern European model of capitalism. Croatian Economic Survey, 19(1) 5-36.

8. Fifek, E., Krajčík, D., Steinhauser, D., \& Zábojník, S. (2015). Hodnotenie konkurencieschopnosti ekonomiky v medżinárodnom porovnaní. Bratislava, Slovakia: Vydavatel'stvo EKONÓM.

9. Horuckova, M. \& Lebiedzik, M. (2015, September). Assessment of the progress of Western Balkans in the economic field of Copenhagen criteria. In M. Tvrdon \& I. Majerova, Proceedings of 12th international scientific conference: economic policy in the European Union member countries. Ostravice, 225-235. 
10. Kašt’áková, E., \& Ružeková, V. (2012). Operácie v zahraničnom obchode: teória a prax. Bratislava, Slovakia: Vydavatel'stvo EKONÓM.

11. Kašt’áková, E., \& Ružeková, V. (2014). Zabraničnoobchodné væ̧taby EÚ s vybranými tretími krajinami III. Bratislava, Slovakia: Vydavatel'stvo Ekonóm.

12. Klimczak, L. (2016). Trade liberalisation and export performance of the Western Balkans. Montenegrin Journal of Economics. 12 (2), 45-60. https:/doi.org/10.14254/1800-5845.2016/12$1 / 3$

13. Mardas, D. (2010). Stabilization and association agreements (SAAs), Europe agreements, and public procurement. Atlantic Economic Journal, 38 (3), 331-343.

14. Miller, T. \& Kim, A. B. (2016). 2016 Index of economic freedom. Promoting economic opportunity and prosperity. Washington and New York: The Heritage Foundation and Dow Jones \& Company, Inc.

15. Murgasova, Z., Nadeem I., Miniane, J., Alasdair, S., Vladkova-Hollar, I. \& IMF staff team (2015). The Western Balkans: 15 years of economic transition. Washington, DC: International Monetary Fund.

16. Osmani, R. (2017). Improved business climate and FDI in the Western Balkans. Journal of Economic and Social Studies, 6 (1), 5-23. https:/doi.org/10.14706/JECOSS16611

17. Reuters. (2015). Teargas released in Kosovo parliament again. Retrieved February, 14, 2016, from http://www.reuters.com/video/2015/12/14/teargas-released-in-kosovo-parliamentag? videoId $=366673727$

18. Rivolta, S. F. (2011). The Balkan conflict and its solutions: Creating conditions for peace, stability and development in the Western Balkans. Southeastern Europe, 35 (1), 153-154.

19. Sekuloska, J. D. (2015, May). Innovation oriented FDI as a way of improving the national competitiveness In E. Gimzauskiene, K. Duoba, X. Pavie, A. Pinnington \& M. Vilka, 20th International Scientific Conference - Economics and Management 2015 (ICEM 2015), Book Series: Procedia Social and Behavioral Sciences, 37-42.

20. The Heritage. (2013-2016). Index. Retrieved January, 27, 2016, from http://www.heritage. org/index/, http://www.heritage.org/index/download

21. Valentina, N. \& Esmeralda, H. (2015, November). Measuring the creative Economy: An assessment of the situation in Western Balkan countries. In K. S. Soliman, 26th International Business Information Management Association Conference, 2536-2546.

22. WBG. (2015-2016). Data. Retrieved 24-25 November, 24-25, 2015, December, 22, 2015, February, 9, 2016 and February, 16-17, 2016 from https://data.worldbank.org/

23. World Economic Forum. (2005-2015). The global competitiveness report. Geneva: WEF.

24. WBG. (2018). GDP per capita (current US\$), Exports of goods and services (\% of GDP). Retrieved March, 8, 2018, from http://databank.worldbank.org/data/reports. aspx? source $=2 \&$ series $=$ NY.GDP.PCAP.CD\&country $=\#$

25. Zubalová, L. (2015). Perspectives of accession of Albania as a full member to EU. Studia commercialia Bratislavensia, 8 (32), 619-630. 


\section{Contact information}

doc. Ing. Zuzana Kittova, PhD., MBL-HSG

University of Economics in Bratislava

Faculty of Commerce

Department of International Trade

Slovakia

E-mail:zurana.kittova@euba.sk

Ing. Dusan Steinhauser, PhD.

University of Economics in Bratislava

Faculty of Commerce

Department of International Trade

Slovakia

E-mail:dusan.steinbauser@euba.sk

ORCID: 0000-0003-0708-9020 